4. R. Dawkins. The selfish gene. OUP, London (1976).

5. R. Dawkins. The selfish gene. Mir, Moscow (1993).

6. S. V. Kanashina. Internet-mem i pretsedentnyy fenomen [Internet-meme and a precedent phenomena]. TGPU Bulletin. No. 4 (193) (2018), pp. 122-127.

7. http://grammarcatz.blogspot.com

DOI 10.15826/B978-5-7996-3081-2.11

\title{
Code Switching as a Peculiar Feature of Digital Communication in Multilingual Settings
}

\section{Mirzoyeva Leila', Syurmen Oxana²,} Dosmakhanova Raikul' ${ }^{3}$, Azhiyev Kanat ${ }^{4}$

1 Suleyman Demirel University, Almaty, Kazakhstan

2 Suleyman Demirel University, Almaty, Kazakhstan

${ }^{3}$ Almaty University of Power Energy, Almaty, Kazakhstan

${ }^{4}$ Almaty University of Power Energy, Almaty, Kazakhstan

Corresponding author: Mirzoeva Leila, mirzoeva@list.ru

\begin{abstract}
Digital communication, which has now taken a leading place among various types of language communication, reflects many specific features of communication in the context of bi - and multilingualism. The article considers switching of language codes as one of the typical features of digital communication and identifies the role of each language involved in this process. The main purpose of the article is to identify the most typical functions of code-switching in Kazakhstani multilingual settings. Our work is based on the material excerpted from 3 chats in WhatsApp messenger by means of continuous sampling. It shows that Russian language in bilingual communication works frequently as a modal and emotional framework of utterance with the predominance of Kazakh language as a means of communication.
\end{abstract}

Keywords: virtual communication, code-switching, code-switching functions, communicative situation, coordinate bilingualism 


\section{Introduction}

The twenty-first century can be considered the epoch of communicative genres' transformation. One of the main peculiarities of new genres is obviously the use of concise texts for transferring various types of information. As N. O. Kushakova states it, "changing communicative needs of contemporary language users provoke constant adaptation of communication means. This leads to the expansion of genre repertoire in digital discourse" [Kushakova, 2016, 62]. The study of these new genre texts in digital discourse is comparatively a new area, so there are no conventional criteria for assessing such texts and their impact on everyday communication in terms of content and expressive potential. Nowadays under the conditions of the pandemic and self-isolation, digital communication has become even more important. Therefore, study of digital communication, especially in multilingual environments, is very relevant.

The specificity of written communication in digital space (via messengers and social networks) determines its main characteristics, such as compactness of provided information, clear goals of a message, asynchronous manner of communication in most cases with a wide range of topics developed in parallel, and having no clear requirements for composition of the message like in informal communication. In our opinion written communication in WhatsApp (one of the most popular messengers in Kazakhstan at the present moment) is a good basis for studying digital communication as it displays all the characteristics of digital communication and is used by a large number of people for different purposes.

Nowadays the transfer from monolingualism to multilingualism and multiculturalism is taking place in Kazakhstani society under the conditions of social and political reconstruction. The specificity of multilingual settings in Kazakhstan determines peculiarities of digital communication, one of which is the switching of language codes. R. Heredia and J. Altarriba note that "code switching, or language mixing, occurs when a word or a phrase in one language substitutes for a word or phrase in a second language" [Heredia and Altarriba, 2001, 164].Code switching is also considered to be a conceptual sphere and defined as a use of language units related to different language systems in the frame of bilingualism [Bagana and Blazhevich, 2010, 64]. Bagana and Blazhevich also state that "in bilingual (multilingual) language settings, native speakers of various languages have the opportunity for contrastive use of different language systems based on intuition. $\mathrm{Bi}$ - or 
multilingual people, i. e. people who speak two (or more) languages, usually "distribute" their use depending on the conditions of communication" [Bagana and Blazhevich, 2010,65].

\section{Code-switching process and its functions}

There are different principles for classifying functions of language code switching. Sociolinguistic classification, for instance, is associated with Blom and Gampertz's theory describing situational and metaphorical (spoken) code-switching. They suggest the following subtypes of spoken code switching (1) mention in speech (quotation); (2) specification of recipient (if the message is addressed to one certain recipient among several possible ones); 3) interjections / exclamations; 4) repetition; 5) evaluation of the message (which is often repeated in another language); (6) personalization / objectification (to express their own opinion bilinguals use one language; objectified information is provided in another language; so use of code switching emphasizes personal opinion) [Blom and Gampertz, 1972, 409].

For our research, we used a classification suggested by R. Jakobson and adapted to sociolinguistic studies by R. Appel and P. Muysken, who highlighted the following social functions of switching language codes: (1) reference function (working in case of impossibility to recall the name of an object in the language of communication); (2) directive function (language selection depending on the inclusion/exclusion of a particular recipient in the certain situation); (3) expressive function; (4) phatic (contact-setting) function in case of using code-switching to maintain, establish, or cancel the contact a with non-native or bilingual interlocutor [Appel and Muysken, 1987, 22]; (5) metalinguistic function and (6) poetic function (e.g. play of words). In our opinion it is also necessary to add the function of ethnic identity suggested by Golovko $[1997,119]$ as it is a common function of code-switching as well.

\section{Population and research methodology}

The authors analysed 92 messages from 3 different groups in WhatsApp. The number of interlocutors in each group was more than 20. In order to excerpt cases of code-switching from WhatsApp messages, the authors used the continuous sampling method. Examples of WhatsApp messages shown in this article preserve all the peculiarities of original spelling and punctuation. It is necessary to point out that most of the errors / spelling 
mistakes in the original messages are presupposed by spontaneous communication and quick responses typical of it, and also by some differences in alphabet used by interlocutors: some of them use Kazakh alphabet (its Cyrillic version), whereas others use the Russian alphabet without specific Kazakh letters (this happens due to peculiarities of digital communication and use of different gadgets).

One of the WhatsApp groups under analysis is a professional community of language instructors. It includes 44 interlocutors who have such common topics and communicative purposes as (a) professional activity; (b) problems which appeared in the course of the Ministry inspection; (c) everyday life, which is the most frequently used theme. Age and gender composition of this group is rather homogeneous. Most of the interlocutors here (41) are women of the age between 35 and 55. This group is an example of communication process between people with the similar social status and level of education.

In two other groups the interlocutors represent various social groups and as a result their levels of language command in both Kazakh and Russian are quite different. One group has a number of participants who are all neighbours. Age and gender composition of this group is also homogeneous ( 21 women of the age between 42 and 65). The communication in this group is mostly about the news and common issues of the neighbourhood. The other group consists of classmates, 29 men and women, of the same age, whose communication is aimed at (a) exchanging information related to a variety of problems (e.g., financial issues related to somebody's business); (b) exchanging emotional attitudes to certain events/facts, important for the members of a particular micro-group; (c) communication on social and everyday topics.

Most of the interlocutors (about $97 \%$ ) in all the three groups are natural bilinguals speaking both Kazakh and Russian languages. The dominant type of bilingualism can be characterized as a coordinative one, which consists in mental mappings of categories and corresponding verbal expression in particular language without mediation of native language.

\section{Results and discussion}

The analysis of the excerpts showed that the predominant function of code-switching in our case is referential. As it has been mentioned above, chatting in WhatsApp requires quick response and immediate reaction, there is no self-reflection at the moment of speech production, so a bilingual 
person has to use a certain word/phrase/set expression in order to refer to a particular concept and respond to the corresponding stimulus. In fact, code-switching is a typical reaction to such a stimulus.

In the communicative situation below the interlocutors in the WhatsApp Group 1 (language teachers) discuss the problems arising in the process of inspection, and also current issues related to the use of the electronic educational system (registration, files uploading, students' attendance). Russian words in Kazakh texts are written in bold:

Situation 1.1(a monologue addressed to all the group members):

Interlocutor 1: Ия, Іскерлік ағылшын тілі менде болған (қазақ бөліміне), “Деловой англ. яз” (орыс бөліміне) (Yes, Business English is my course for both Russian and Kazakh groups (the name of the course is given in both Russian and Kazakh - depending on students' predominant language - Russian or Kazakh)

Interlocutor 2: Әрине салам. Бірақ қай жеріне? Летник деген бөлім ба, бірдеңе ашып берсе, с названием предмета, без проблем салам ғо. Просто не вижу, куда загрузить. (Hi, of course, I will (do it). But where (to upload)? Summer course - where is it? If they show the name of the discipline on the site, there will not be any problem. But I cannot see where to upload (the last phrase is completely in Russian).

So, the summary of the problem is given in Russian whereas all the other utterances show the combination of both languages. But it is also quite obvious that the Russian language performs reference (летник=sитmеr courses) and expressive (без проблем - no problem) functions. It is really important that the same discipline nominated in different languages, Kazakh and Russian (“Деловой англ яз”/ Іскерлік ағылшын тілі) have been recognized as different subjects, and this fact also proves our opinion concerning the predominance of reference function performed by the Russian language in such communicative situations. This fragment has been extracted from WhatsApp communication as a very typical one, and it represents the "framework" function of Russian language in the process of spontaneous bilingual communication.

Situation 1.2:

Interlocutor 1 Доброе утро всем. (Name, patronimyc name of the Faculty dean), пароль сурап тур... номер совещания вводим, затем введите пароль дид, пароль жок, кералмай турмыз (Good morning everybody (in Russian). (Name, patronimyc name of the Faculty dean as a specific form 
of address in Russian), (the system) asks a password. We enter the number of the meeting (in Russian), and the password is requested (it says - in Kazakh). We don't have the password, so we are unable to see anything.)

Interlocutor 2 Шет тилине умкд (Surname of the teacher 1) апайга давнооо айтылган. 1 тал умкд. (Name of the teacher 2)-апай ведёт же экономфактн букыл 1 курстарына(и УМКД для всех разрабатывает) (Teacher 1 is responsible for the syllabus and supplementary materials for Foreign language so long ago. Teacher 2 (Interlocutor 2 used a specific Kazakh form of address) conducts (classes) for all the Faculty of Economics $1^{\text {st }}$ year students; so she is responsible for the package).

This example shows the importance of the common context for all the interlocutors. Although these two paragraphs seem to be separate monologues, the second one is actually the reaction to the first one and follows it as a part of a longer dialogue. In our opinion, code-switching from Kazakh into Russian in this case structures the communicative act. The Russian language here (a) performs reference function in the process of spontaneous communication when the interlocutors have no time to think about the appropriate words in Kazakh; (b) works as a modal and emotional "framework" as it is used to express the attitude (ведёт же /conducts (classes), давнооо / so long ago - together with the graphic emphasis). Thus, in these cases code-switching should be considered as a means of 'information gap overcoming'.

Situation 1.3 (a brief monologue related to the Ministry of Education inspection process):

Interlocutor 1 (The name of the teacher who is the author of the course materials) пособие табу керек... Найдите пособия (the author's name is repeated) срочно комиссия сураптур (We have to find the course materials by (the teacher's name) (in Kazakh)... / Find (the author's name) the course materials (in Russian). The commission wants them immediately.

Here, the phatic (contact-setting) function of code-switching is represented. It also goes along with the directive and expressive functions, as the repeated phrase in Russian is addressed to those group members whose language command in Kazakh is not good enough. Expressive function (intensification of the request and emotional tension generation - срочно / immediately) is performed by the Russian word as it works as the emotive component of the utterance.

As a result, we can state that all these excerpts show that the most frequent function performed by code-switching in professional communication 
is the reference one; other functions such as expressive and contact-setting are also represented in this chat, but they are not so typical.

On the other hand, Group 2 and Group 3 are different from the first one to some extent, and the most important difference between them lies in the purpose of communication. Hereunder, we provide some extracts from the neighbors chat related to the problems of everyday life.

Situation 2.1 is related to the problem of keeping the street clean and tidy. Two neighbours discuss the problem of garbage in the street; one of them makes excuses and explains the situation. She said that the students who rented her house collected garbage inside her garden instead of going to somebody's garbage bin. Being a native speaker of Kazakh, in this message she used this language only, but for the key word — garbage — the Russian word with the incorrect spelling - мyсыр - was used. Definitely, there are Kazakh equivalents for those two words (бочка - бөшке, мусор - қоқыс), but the two native speakers of Kazakh prefer using Russian words. So, this case can also be considered as the reference function of code-switching.

Interlocutor 1: Сәлеметсіздер ме студенттер менде тұрды бірақ олар есіктін алдынан бочкаға салмайтын біреудің есік алдына апармақ түгілі. Мен осыны қозғазым келіп жүр еді менің бочкам сыртта мусыр болады әрдайым ішінде ал мусырды мен келіп шығармасам шығарылмайды біреудің ауласына тастау болмайды ғой ұят зат (see the explanation above)

Interlocutor 2: Сиздин студенттериниз турганда, всегда сыртта мусор жататын, потом оны иттер шашады кошеге, мен куйеумен барып оны жинап журдик талай. Мен озим например мусорды никогда кошеге шыгарып коймаймын, только машинаны корсем сол кезде гана (Your students always (Russian word) leave the garbage (Russian word) outside, so that stray dogs throw it about on the street, and then me together with my husband collect it. As for me, for example, I have never (Russian part of the phrase) left the garbage on the street; only (Russian word) if I see the dustbin lorry coming I do it).

From this chat, we have excerpted the most typical examples like the abovementioned one, and it also demonstrates the predominance of reference and expressive functions of code-switching, but in this case speech personalization by means of code-switching should also be highlighted $(\mathrm{MeH}$ озим например / As for me, for example etc.) Thus, pragmatic information is represented in two languages, but in order to highlight the emotive information and to stress some of its pieces, the interlocutors use Russian. 
See also:

\section{Situation 2.2}

Due to the pandemic, this chat was full of the information about deaths, the spread of Coronavirus all over the Republic of Kazakhstan, and other bad news. So, some group members said that it is not necessary to disseminate the information of such kind in the chat.

Interlocutor 1: Осы чатқа бір жаман информация жібермейікші. Ал енді анандай информацияларды оны былайда интернетте толып жатыр (Please do not post negative information (Interlocutor 1 uses Russian word instead of Kazakh equivalent - ақпарат) here in this chat because there is plenty of it in the Internet (there is also an analogue of this lexical unit in Kazakh language - ғаламтор)).

Interlocutor 2: Общий чатқа керек емес нәрсені салып жатырсыңдар (Yes, we do not need such information in our common (Russian word) chat).

Interlocutor3: Салеметсиздерме, келисемин, мен вообе никогда ничего жибермеймин (Hello everybody, I agree, I have never posted anything (Russian words)).

The predominance of reference and expressive functions together with personalization is represented clearly in these excerpts. Also, all those examples comply with C. Myers-Scotton's statement: "Embedded Language (EL) islands (phrases from other varieties participating in the clause) are allowed if they meet EL well-formedness conditions, as well as those ML (Matrix Language) conditions applying to the clause as a whole (e.g. phrase placement)" [Myers-Scotton, 2002, 21]. There are also many cases of code switching in Group 3. For instance, the situation below (discussion about classmates' business perspectives) represents a similar pattern to the abovementioned pieces of communication with some specific features:

\section{Situation 3.1}

Interlocutor1 asked a classmate (Interlocutor 2) about money for his prospective business: to grow mushrooms in greenhouses and sell them to restaurants and cafes. Interlocutor 2 began to give him advice: now, restaurants and cafes are experiencing stagnation; so mushrooms are impossible to be sold. Angry Interlocutor 1 said he did not need any advice; the only thing he needed is some money. Interlocutor 2 said, that if he had nothing but a lot of dreams he would get nothing. Then Interlocutor 2 said the third classmate had told him to contact their lady-classmate without any trouble as she had promised to help them 'anywhere, anytime'. Interlocutor 1 and Interlocutor 
2 recalled this with great pleasure but, on the other hand, Interlocutor 1 did not want to be beholden to a lady, even if she was their classmate.

Interlocutor1 Кластас братаным, маған көмек берсең! Өткенде айттым ғой.

Interlocutor 2 Братишка, сен точно айтмаған. Не үшін? Ресторан кафелер закрыт болғаны қашан. Сен ұтыласын ғой (in this response, the form of address is really specific, as it it is the Russian diminutive for the word brother; also, Interlocutor2 used Russian words instead of their Kazakh equivalents - ресторан - мейрамхана, закрыт - жабық тұр in order to nominate objects or state/process). Түсінбейсің ба?

Interlocutor 1: Мен всегда прямо айтамын. Маған не ақыл нужен, а ақша нужен! Code switching in the previous utterance produced by Interlocutor 2 stimulated Interlocutor 1 to do the same. Thus, the structure of the sentence above is closer to Russian than to the Kazakh one, so Russian is used as a syntactic framework (the sample of negation and even words themselves (I do not need any advice, I need some money - не ақыл нужен, а ақша нужен)

Interlocutor 2: Ақшаны табу оңай дейсің ба?

Interlocutor1: Сен маған сенбейсің ба?

Interlocutor 2: Сен о чем это? Көп мечтаешь, аз получишь (here we face the case of the poetic function, because it seems to be a play of words: Interlocutor 2 transformed the Russian saying Много хочешь, мало получишь (you want a lot but will get little, meaning keep dreaming) using Kazakh adverbs together with Russian verbs. This transformation of the common saying produces comic effect, strengthened by the previous phrase where there is just one Kazakh word - a pronoun Сен (you).

Interlocutor 1: Сендер ұрыспаңдар. Туысқан емес сіңдер ма?

Interlocutor2: Былтыр кездесуден кейін Бақшагүлдің үйінде (classmate's name) сен не дедің?

\section{Interlocutor 1: Не помню}

Interlocutor 2: Мен вспоминаю твои слова. Керемет сказано - Also, we consider it as a case of word play like in the previous case (see above)

Interlocutor 1: Сонда Бақша не деп еді? Жігіттер сендер үшін жаным садақа деп еді.

Interlocutor 2: Онымен не айтқың келеді?

Interlocutor1: Бақша саунасынан көп табады емес пе? Содан?

Interlocutor 2: Ол мировой. Саған отказ бермейді. 
Interlocutor 1: Ой, айтпақшы Бақшагүлден сұрасам болады екен ия. Ай сол қатынға қарыз болғым келмейд.

Here, we see a whole 'palette' of code switching: first, there is an inclusion of the word or component from Russian into communicative process hold in Kazakh; a change of the independent components in Russian and Kazakh within the sentence, as well as a play of words produced by Interlocutor 2 . However, there is a complete mutual understanding between the interlocutors: both the author of the utterance and his partners in the communication have sufficiently good language command in order to perceive the given word play in an appropriate way.

Within the framework of our research, the referential function is shown in most of the contexts (49), which is about $53 \%$ of all code-switching cases. The second function we consider as a typical one, the expressive (emotive) function ( 27 cases, i. e. about $30 \%$ ). It is also possible to identify extracts with poetic function (word play; this function of code-switching is represented in 9 cases, which is about $9 \%$ ). And, finally,7 cases (about $6 \%$ of the total number) represent directive function; but it should be pointed out that there is no rejection of any interlocutor. In our opinion, it can be regarded as evidence of 'language tolerance' in digital communication in Kazakhstan which represents general rule of the language situation.

\section{Conclusion}

Digital communication in multilingual settings is currently an almost unexplored area. Results of our research prove that referential function of language code-switching predominates in digital multilingual communication, which in our opinion, is predetermined by peculiarities of communication in WhatsApp, presupposing (a) a quick spontaneous response to a particular communicative stimulus; (b) a minimum of reflection on language form; (c) the affinity of written communication to the oral. As it was stated before, in the case of social distance and self-isolation due to the pandemic, this way of communication is becoming more and more important.

All the above mentioned allows us to say that in the analysed cases, the Kazakh language acts as a structural "frame", while Russian performs the function of expressing emotions and provides speakers with the opportunities for using it for such stylistic function as word play. Monitoring language code-switching processes in digital communication via messengers and social networks makes it possible to trace the attitude to the use 
of a language in a multicultural and multilingual environment, and also allows us to identify the range of functions performed by a certain language in a multilingual context.

\section{Conflict of Interest}

The authors have no conflict of interest to declare.

\section{References:}

1. N. O. Kushakova. Specificheskie zhanry sms-diskursa [Specific genres of sms discourse]. Kommunikativnye issledovanija [Communication research], № 1 (7) (2016), pp. 60-72.

2. R. Heredia, J. Altarriba. Bilingual Language Mixing: Why Do Bilinguals Code-Switch? Current Directions in Psychological Science, Vol. 10, Issue 5 (2001), pp. $164-168$.

3. Zh. Bagana, Ju. S. Blazhevich. K voprosu o perekljuchenii kodov [The question of Code Switching]. Serija Gumanitarnye nauki, № 12 (83) (2012). Issue 6.

4. J.-P. Blom, J.J. Gumperz. Directions in Sociolinguistics. The Ethnography of Communication. Holt, Rinehart and Winston, Inc., New York (1972), pp. 407-434.

5. R. Appel, P. Muysken. Language contact and bilingualism: Edward Arnold, London; Baltimore, MD (1987).

6. E. V. Golovko. Mednovskih aleutov jazyk. Jazyki mira. Paleoaziatskie jazyki. Indrik, Moscow (1997), pp. 117-125.

7. C. Myers-Scotton. Contact Linguistics. Oxford University Press, Oxford (2002). 